\title{
LEADERSHIP CHARACTERS IN MALAYSIAN RELIGIOUS-NGOS: AN INTRODUCTORY OVERVIEW
}

\author{
Mohd Faridh Hafez Mhd Omar ${ }^{1}$ \\ Sharifah Hayaati Syed Ismail ${ }^{2}$ \\ Ishomuddin Sulaiman Ilyas ${ }^{3}$
}

\begin{abstract}
Leadership is a key function and process to unlock the effectiveness and enhancement of any organization's development, including Religious-NGOs (RNGOs). This can be attained via three main characteristics, which are charismatic, transformational and servant leadership. Previous research has proved that these characteristics are relevant for NGOs, but little was found for RNGOs. RNGO is a form of NGO that is well-known for its active role in contributing to a harmonious and religious society. This paper focused on the concept of leadership in RNGOs and an introductory to the identity of Malaysian Islamic RNGOs that are diverse by ethnic identities. This study was qualitative in nature and depended heavily on existing literature and official reports. The study found that all three selected Islamic RNGOs that represent the Malay Muslims, Chinese Muslims and Indian Muslims adopt and practice charismatic, transformational and servant leadership in executing their organizations' objectives,
\end{abstract}

1 Senior Lecturer, Faculty of Leadership \& Management, University of Science Islam Malaysia, 71800, Nilai Negeri Sembilan, faridhomar@usim.edu.my

2 Associate Professor, Department of Siasah Syar iyyah, Academy of Islamic Studies, University of Malaya, 50603 Kuala Lumpur, sashsiaq@um.edu.my

3 Professor, Muhammadiyah Malang University, 65122 East Java, Indonesia, ummishom@gmail.com 
which could possibly be a yardstick to effective RNGO leadership development in the future.

Keywords: leadership characters, religious-NGOs in Malaysia, charismatic, transformational, servant

\section{INTRODUCTION}

Leadership studies have witnessed a dramatic increase over the last decade. They have resulted in a diversity of leadership developments and theories. A very stunning finding in the scholarly research on leadership is that it has advanced from theoretical discussions on general leadership processes towards a phenomenal evolvement which leads to a key of investigation. ${ }^{4}$ In this context, it has expanded into two dimensional micro and macro processes in leadership. ${ }^{5}$ Micro leadership involves a way of understanding perceptions, emotions and cognition, whereas macro leadership focuses on the outcomes of social-relational context ${ }^{6}$ and dynamism of the follower-leader relationship. ${ }^{7}$ For both processes, as well as the huge roles played by leaders within the complexity of the organizational systems, leaders are defined as central in determining any type of organizations' success and effectiveness, including the public and private sectors, as well as non-governmental organizations (NGOs).

Conceptually, the meaning of leadership, as found by Rost, was extended into 200 different definitions in various categories. Burns emphasized that the meaning of leadership is the most observed, yet the least understood phenomenon based on Rost's findings. ${ }^{8}$ Looking at the broad definition of

4 Dinh, J. E., Lord, R. G., Gardner, W. L., Meuser, J. D., Liden, R. C., \& Hu, J., 'Leadership Theory and Research in the New Millennium: Current Theoretical Trends and Changing Perspectives,' The Leadership Quarterly, vol. 25/1 (2014): 36-62.

5 Dinh, J. E. \& Lord, R. G., 'Implications of Dispositional and Process Views of Traits for Individual Difference Research in Leadership,' The Leadership Quarterly, vol. 23/4 (2012): 651-669.

6 Johnson, R.E., 'Not all Leader-Member Exchanges are Created Equal: Importance of Leader Relational Identity,' The Leadership Quarterly, vol. 21/5 (2010): 796808.

7 Dinh, J. E., Lord, R. G., Gardner, W. L., Meuser, J. D., Liden, R. C., \& Hu, J., 'Leadership Theory and Research in the New Millennium: Current Theoretical Trends and Changing Perspectives,' 36.

8 Burns, James, Leadership (New York: Harper \& Row, 1978), 19. 
leadership which encompasses goals, skills and the background of the leader himself, a direct definition can be seen from Jay Lorsch's 'as an individual who influences others to follow him or her' ${ }^{9}$ However, many perceived that defining leadership should not exclude these three important elements common and shared mission, winning the subordinates' hearts and minds, and power or authority. A comprehensive definition of leadership was given by James Macgregor Burns. Burns defines leadership as a mobilization process undertaken by individuals who are using the power they draw from motives, values and access to resources in the context of competition and conflict during their pursuit of goals. ${ }^{10}$ Despite the definition of leadership is continuously and widely debated to suit different contexts, approaches and mechanisms, at the same time, failing to produce a good leader with leadership characteristics will lead to a dysfunction in achieving an organization's goals.

Therefore, this article investigated leadership characteristics applied by Malaysian Religious-NGOs (RNGOs) which adopt Islam as the pillar or principle for their establishments. Besides, due to Malaysia's uniqueness of multiracial identities consisting of Malays, Chinese and Indians, the exploration of how these identities have built their respective organizations and contributed to the relationships with people and other parties is best explained based on what leadership characters are involved. This article suggests three best characteristics; charismatic, transformational and servant leadership to be adopted in leading Islamic-RNGOs. These characters are wellembedded in the presence of the organizations as well as their leaders despite the challenges faced. These can probably be seen and analyzed from multiple dimensions of organizational presence, such as missions and visions, media reports, achievements, conducted programs, productions, and public feedback. However, this writing is a recent effort to enhance and refresh the existing literature and theories of leadership for the benefit of the current discussions and evaluations, mainly toward Islamic RNGOs in Malaysia. It is hoped that it could overturn the 'trust deficit' that hampers the 'government' at the time being.

\section{OVERVIEW OF THE DEFINITION OF NGO LEADERSHIP FROM WESTERN AND ISLAMIC PERSPECTIVES}

The huge number of Islamic-based organizations, to an extent, can be narrowed down into racial-based identity. Meanwhile, leadership is the key

\footnotetext{
$9 \quad$ Jay Lorsch, 'A Contingency Theory of Leadership,' in Handbook of Leadership Theory and Practice, ed. Nitin Nohria \& Rakesh Kurana (Boston, MA: Harvard Business Press, 2010), 414.

10 Burns, James, Leadership, 20.
} 
issue in determining the success of these organizations. Leadership is defined in both fictional and speculative, yet still within the range of academic studies and scholarly treaties. According to Roger Gill, there is still no definite end for leaders to define leadership in the popular spectrum. ${ }^{11}$ Nevertheless, criticisms on how leadership was defined should not be ignored. It could help in addressing the lack of consensus on what leadership is in the actual practice. To some, this lack of consensus led to mixing up the definitions of leadership and management, whilst most agreed that they are separable issues as stated by the United Kingdom's Investors-in-People Institution (IIP), which states that "Leadership and management are almost impossible to define because they mean different things to every organization". ${ }^{12}$

Departing from this understanding, more than 200 leadership definitions were discovered by Rost, which were later defined accordingly into relational, situated, patterned and formal/informal nature by Carter et.al. This is due to the understanding that leadership is a phenomenon and that contemporary definitions also have an advanced view of leadership when situated in a specific context. ${ }^{13}$ These four categories have well explained the nature of RNGO leadership practices as a form of NGO. Religious organizations can be considered quite fluid in their operational management as they are believed to have zero bureaucracies compared to government and business entities. ${ }^{14}$ As mentioned earlier, the definition of leadership consists of three elements common and shared mission, wins the subordinates' hearts and minds, and power or authority. Table 1 presents a compilation of definitions from the past centuries of leadership theories.

Table 1: Leadership Definitions

\begin{tabular}{ll}
\hline Author (Year) & \multicolumn{1}{c}{ Leadership Definition } \\
\hline Follet (1925) & "It is possible to develop the conception of power-with, \\
& $\begin{array}{l}\text { a jointly developed power, a coactive, not a coercive } \\
\text { power . . . power is capacity... power-with is jointly } \\
\text { developing power" (pp. 101, 109, 115). }\end{array}$
\end{tabular}

11 Gill, Roger, Theory and Practice of Leadership (London: Sage Publications, 2013), 6-10.

12 Investors in People UK. Leadership and Management. (London: IIP, 2007). 18.

13 Carter, D. R., DeChurch, L. A., Braun, M. T. \& Contractor, N. S., 'Social Network Approaches to Leadership: An Integrative Conceptual Review,' Journal of Applied Psychology, vol. 100/3 (2015): 597.

14 White, S. C., Devine, J. \& Jha, S., 'The Life A Person Lives: Religion, Well-being and Development in India,' Development in Practice, vol. 22/5-6 (2012): 651-662. 


\begin{tabular}{ll}
\hline Author (Year) & \multicolumn{1}{c}{ Leadership Definition } \\
Pigors (1935) & $\begin{array}{l}\text { "Leadership is a process of mutual stimulation which, } \\
\text { by the successful interplay of individual differences, } \\
\text { controls human energy in the pursuit of a common } \\
\text { cause" (p. 378). }\end{array}$
\end{tabular}

Gibb (1954)

"Leadership is probably best conceived as a group quality" (p. 884).

French \& Raven

"Our theory of social influence and power is limited to influence on the person, $\mathrm{P}$, produced by a social agent, $\mathrm{O}$, where $\mathrm{O}$ can be either another person, a role, a norm, a group or a part of a group . . . The "influence" of $\mathrm{O}$ must be clearly distinguished from O's "control" of $\mathrm{P}$ " (p. 151).

Hollander \&

Julian (1969)

There is a "need to attend to leadership as a property of the system of a group; recognize the two-way influence characterizing leader-follower relations" (p. 387).

Dansereau et al.

"The vertical dyad is the appropriate unit of analysis

Burns (1978) for examining leadership processes" (p. 47).

"Surely it is time that . . . the roles of leader and follower be united" (p. vi).

Fernandez (1991) "We argue that leadership, particularly that aspect of leadership which is reflected in respect, is inherent in the relations among individuals, not in the individuals themselves" (p. 37).

Hollander (1993) "Without followers there are plainly no leaders or leadership" (p. 29).

Klein \& House "Charisma resides not in a leader, nor in a follower, but (1995) in the relationship between a leader who has charismatic qualities and a follower who is open to charisma, within a charisma-conducive environment" (p.183).

Meindl (1995)

"The romance of leadership notion emphasizes followers and their contexts for defining leadership itself and for understanding its significance" (p. 330).

Osborn et al.

"Leadership is socially constructed in and from a (2002) context where patterns over time must be considered and where history matters" (p. 798). 


\begin{tabular}{|c|c|}
\hline Author (Year) & Leadership Definition \\
\hline Hogg (2001) & $\begin{array}{l}\text { "Leaders may emerge, maintain their position, be } \\
\text { effective, and so forth, as a result of basic social } \\
\text { cognitive processes" (p. 186). }\end{array}$ \\
\hline $\begin{array}{l}\text { Pearce \& Conger } \\
(2003)\end{array}$ & $\begin{array}{l}\text { "Leadership is broadly distributed among a set of } \\
\text { individuals instead of centralized in hands of a single } \\
\text { individual who acts in the role of superior" (p. 1). }\end{array}$ \\
\hline $\begin{array}{l}\text { Howell \& Shamir } \\
\text { (2005) }\end{array}$ & $\begin{array}{l}\text { "Followers' self-concepts play a crucial role in } \\
\text { determining the type of relationship they develop with } \\
\text { the leader" (p. 97). }\end{array}$ \\
\hline $\begin{array}{l}\text { Balkundi \& } \\
\text { Kilduff (2006) }\end{array}$ & $\begin{array}{l}\text { "Our network approach locates leadership not in } \\
\text { the attributes of individuals but in the relationships } \\
\text { connecting individuals" (p. 942). }\end{array}$ \\
\hline Uhl-Bien (2006) & $\begin{array}{l}\text { "I identify relational leadership as a social influence } \\
\text { process through which emergent coordination ... and } \\
\text { change ... are constructed and produced" (p. } 655) \text {. }\end{array}$ \\
\hline $\begin{array}{l}\text { Hackman \& } \\
\text { Wageman (2007) }\end{array}$ & $\begin{array}{l}\text { "One does not have to be in a leadership position to be } \\
\text { in a position to provide leadership" (p. } 46 \text { ) }\end{array}$ \\
\hline Drath et al. (2008) & $\begin{array}{l}\text { "Leadership has been enacted and exists wherever and } \\
\text { whenever one finds a collective exhibiting direction, } \\
\text { alignment, and commitment" (p. 642). }\end{array}$ \\
\hline $\begin{array}{l}\text { Friedrich et al. } \\
(2009)\end{array}$ & $\begin{array}{l}\text { "Multiple individuals within the team may serve as } \\
\text { leaders in both formal and informal capacities" (p. } \\
\text { 933). }\end{array}$ \\
\hline DeRue (2011) & $\begin{array}{l}\text { "[Leadership is] a social interaction process where } \\
\text { individuals engage in repeated leading-following } \\
\text { interactions, and through these interactions, co- } \\
\text { construct identities and relationships as leaders and } \\
\text { followers" (p. 126). }\end{array}$ \\
\hline $\begin{array}{l}\text { Morgeson et al. } \\
(2010)\end{array}$ & $\begin{array}{l}\text { "Leadership is the vehicle through which [team needs] } \\
\text { are satisfied, regardless of the specific leadership } \\
\text { source" (p. 5). }\end{array}$ \\
\hline Yukl (2010) & $\begin{array}{l}\text { "Leadership is the process of influencing others to } \\
\text { understand and agree about what needs to be done and } \\
\text { how to do it, and the process of facilitating individual } \\
\text { and collective efforts to accomplish shared objectives" } \\
\text { (p. 8). }\end{array}$ \\
\hline
\end{tabular}




\begin{tabular}{ll}
\hline \multicolumn{1}{c}{ Author (Year) } & \multicolumn{1}{c}{ Leadership Definition } \\
$\begin{array}{l}\text { Eberly et al. } \\
\text { (2013) }\end{array}$ & $\begin{array}{l}\text { "We posit that what gives rise to the phenomenon of } \\
\text { leadership is a series of often simultaneous event cycles } \\
\text { between multiple loci of leadership" (p. 4). }\end{array}$ \\
Yammarino (2013) & "Leadership is a multi-level... leader-follower \\
& interaction process that occurs in a particular situation \\
& (context) where a leader . . . and followers... share a \\
purpose . . . and jointly accomplish things... willingly" \\
(p. 20). \\
"Leadership is a social process that involves interactive \\
Lord \& Dinh \\
(2014)
\end{tabular}

Source: Summarized by the authors

In giving a balanced overview of leadership definitions, an Islamic perspective should be taken into account. In Michael H. Hart's book entitled "The 100: A Ranking of the Most Influential Persons in History", Prophet Muhammad [p.b.u.h] is listed as the first man of the world's most influential persons throughout the human history. According to Hart as to why Prophet Muhammad [p.b.u.h] was listed as number one, he was the only man in history who was supremely successful on both religious and secular levels. ${ }^{15}$

Leadership in Islam refers to the practices, as well as sayings of Prophet Muhammad [p.b.u.h], which entails leadership as a guardianship. The definitions of leadership from an Islamic perspective are composed as in Table 2 below;

Table 2: Leadership Definitions from an Islamic Perspective

\begin{tabular}{ll}
\hline \multicolumn{1}{c}{ Author (Year) } & \multicolumn{1}{c}{ Leadership Definition } \\
\hline Safi (1995) & "the capacity to mobilize a group of people towards a \\
& $\begin{array}{l}\text { set of articulated goals, and to ensure their continuous } \\
\text { cooperation for the realization of these goals" (p.206) }\end{array}$ \\
Mohd Yusof (1990) & $\begin{array}{l}\text { "Leadership is the influence exerted by an individual } \\
\text { in a situation directed towards achieving specific } \\
\text { objective or objectives." (p.204) }\end{array}$
\end{tabular}

15 Michael, H. Hart, The 100: A Ranking of the Most Influential Persons in History (New York: Kensington Publishing Corporation, 1978), 8. 


\begin{tabular}{|c|c|}
\hline Author (Year) & Leadership Definition \\
\hline $\begin{array}{l}\text { Badawi and Beekun } \\
\text { (1999) }\end{array}$ & $\begin{array}{l}\text { "... leadership in Islam is not reserved for a small } \\
\text { elite. Rather, depending upon the situation, every } \\
\text { person is the "shepherd' of a flock, and occupies a } \\
\text { position of leadership" (p.5) }\end{array}$ \\
\hline $\begin{array}{l}\text { Andek Kelawa } \\
\text { (1999) }\end{array}$ & $\begin{array}{l}\text { "leadership in Arabic language covers a wide area } \\
\text { and is not limited to state or racial (group) leadership, } \\
\text { but extends to leadership in the fields of knowledge, } \\
\text { worship as well as custody and guardianship of a } \\
\text { trust." (p.12) }\end{array}$ \\
\hline Khan (2007) & $\begin{array}{l}\text { "Leadership in Islam is considered as a trust and } \\
\text { a responsibility. A leader is required to meet his } \\
\text { obligations to God, the Supreme Power as well as to } \\
\text { discharge his duties towards his followers to the best } \\
\text { of his abilities." (p.2) }\end{array}$ \\
\hline $\begin{array}{l}\text { Omar, Mahyudin } \\
(2012)\end{array}$ & $\begin{array}{l}\text { Leadership is important in regulating for a better and } \\
\text { more secure human life ... process which mobilizes } \\
\text { and individual or society to achieve the desired } \\
\text { objectives. (p.1399) }\end{array}$ \\
\hline Omar et.al (2019) & $\begin{array}{l}\text { "... is a responsibility and trust that leaders assume } \\
\text { with their followers...considered as part of religious } \\
\text { devotion." (p.178) }\end{array}$ \\
\hline $\begin{array}{l}\text { Nabeel Al-Azami } \\
(2019)\end{array}$ & $\begin{array}{l}\text { Leadership is about; power and authority, justice, } \\
\text { transformation of people and society, and involved } \\
\text { multidimensional and multilayered personality. } \\
\text { (p.18-19) }\end{array}$ \\
\hline
\end{tabular}

Source: Summarized by the authors

The notion of leadership's definition in an organizational structure has dwelled into the public domain, private and NGOs. For example, in an NGO leadership development, a comprehensive means of assisting to develop leadership capabilities for NGOs is an urgent need which should consist the dimensions of NGO, effective NGO leaders, and be alert on the changes of external development. ${ }^{16}$ As Hailey and James further explained, as NGOs face particular management challenges distinct from those faced by governments

16 Hailey, J. \& James, R., 'Trees Die from the Top: International Perspectives on NGO Leadership Development,' Voluntas: International Journal of Voluntary and Nonprofit Organizations, vol. 15/4 (2004): 343-353. 
or for-profit organizations, they have to ensure their readiness in facing future complexity, mainly in leadership processes and managerial problems. ${ }^{17} \mathrm{In}$ discussing the importance of leadership in Islamic movements, including Islamic RNGOs, Yusuf al-Qaradawi and Sayyid Abul 'ala Mawdudi have expressed their major concern on 'leadership' and prioritized it as an important element that must receive attention. ${ }^{18}$

\section{LEADERSHIP CHARACTERS FOR RELIGIOUS-NGOS}

Considering the global reports on leadership from Edelman Trust Barometer 2016 and 2017 and Outlook on the Global Agenda 2015, leadership development for NGOs is critical in time. It is a must to differentiate the roles of NGOs (including RNGOs), government and private sector as the former offers liquidity in leadership practices whilst both of the latter are strictly stringent in achieving vision and mission statements. Richard K. Ghere puts a comprehensive proposition on NGO leadership as distinguishable by its prevalent reliance on cognitive processes to transform altruistic aspirations into operational realities. ${ }^{19}$ Character in leadership is essential despite the nature of the organizational environment. It is believed that a leader with character can give an organization a significant competitive advantage. Connaughton emphasizes that a lead character is an antidote to organizational fatigue, including in a care unit such as the hospital. ${ }^{20}$

This was supported by Hailey who identified four common themes that run through leadership theory and fit with religious NGOs; leadership is a process, leadership involves influence, leadership occurs in group context, and leadership involves the attainment of goals. ${ }^{21}$ Relating to that, Chin and Wendy found common characters shared by servant, charismatic and

17 Hailey, J. \& James, R., 'Trees Die from the Top: International Perspectives on NGO Leadership Development,' 343.

18 Yusuf al-Qardhawi, Priorities of the Islamic Movement in the Coming Phase, trans. S.M Hasan Al-Banna (UK: Awakening Publications, 1992). 15; Hussain, Muzaffar, 'The Islamic Polity of Abdul A'la al-Mawdudi,' VFAST Transactions on Islamic Research, vol. 3/1 (2014): 13-21.

19 Ghere, R. K., 'NGO Leadership and Human Rights,' http://ecommons.udayton. edu/cgi/viewcontent.cgi?article $=1045 \&$ context $=$ pol_fac_pub, accessed on 21 September 2017.

20 Connaughton, M. J., \& Hassinger, J. 'Leadership character: antidote to organizational fatigue.' Journal of Nursing Administration, vol. 37/10 (2007): 464-470.

21 Hailey, John. 'NGO leadership development.' Praxis paper 10 (2006). 
transformational leadership in leading and managing organizations like NGOs, as well as RNGOs. ${ }^{22}$ Thus, this paper put these three leadership characters; charismatic leadership, transformational leadership and servant leadership as a central discussion. In the authors' view, these three are much appropriate to be practiced and applied together with religious beliefs and values as the organizational principles and objectives are in the context of RNGOs. The three characteristics of leadership are discussed below;

\section{Charismatic Leadership}

According to Politis, charismatic leadership provides room for vision and energy to be applied through knowledge-sharing within the organization. ${ }^{23}$ However, a cause is needed to let out the leaders' charismatic attitude. The cause, according to Jayakody, is mainly visible during a crisis. ${ }^{24}$ Yet, Politis claimed that culture is embedded within a certain condition of the country, people and organizational structure, which should be taken into account as crisis that occurs are diverse in number. ${ }^{25}$ For example, in Taiwan, researchers found that charismatic leadership has a significant impact on employee outcomes. ${ }^{26}$ Therefore, charismatic leadership can be perceived in terms of vision, risk-taking, challenges and encouragements, as well as energy and determination. ${ }^{27}$ However, it is far from being termed as 'motivational' leadership. ${ }^{28}$

The term 'charisma' is mostly used in political discussions as a political leader who has substantial attributes can influence his or her followers to

22 Chin, D. T., \& Wendy A. Smith, 'An Inductive Model of Servant Leadership: The Considered Difference to Transformational and Charismatic Leadership,' Working Paper 43/06, Department of Management, Monash University (2006), 1-19.

23 Politis, John D., 'Transformational and Transactional Leadership Enabling (Disabling) Knowledge Acquisition of Self-Managed Teams: The Consequences for Performance,' Leadership \& Organization Development Journal, vol. 23/4 (2002): 186-197.

24 Jayakody, J. A. S. K., 'Charismatic Leadership in Sri Lankan Business Organizations,' Journal of Management Development, vol. $27 / 5$ (2008): 480-498.

25 Dion, Michel, 'Are Ethical Theories Relevant for Ethical Leadership?' Leadership \& Organization Development Journal, vol. 33/1 (2012): 4-24.

26 Dion, Michel, 'Are Ethical Theories Relevant for Ethical Leadership?' 8.

27 Javidan, Mansour \& David A. Waldman, 'Exploring Charismatic Leadership in the Public Sector: Measurement and Consequences,' Public Administration Review, vol. 63/2 (2003): 229-242.

28 Gill, Roger, Theory and Practice of Leadership, 50. 
execute his or her orders. House and Baetz defined a charismatic leader as a person who 'by the force of their abilities are capable of having profound and extraordinary effects on followers' ${ }^{29}$ In contrast to the idea of charismatic leaders are politicians, Willner insisted that charismatic leadership is neither personality-based nor contextually-determined, but rather the phenomenon is largely relational and perceptual. ${ }^{30} \mathrm{He}$ later stressed that "It is not what the leader is but what people see the leader as that counts in generating the charismatic leadership". ${ }^{31}$

Building up from the given definitions and conceptual discussions, values in charismatic leadership are considered primary assessments. The values that entrench for charismatic leadership vary among different researchers. For example, some researchers tend to focus on the content of the vision and consider communication style in delivering speeches as key factors. Inversely to others, innovative strategic vision, revealing true identity when attending members' needs, displaying unconventional behavior, risk-taking and showing sensitivity to the environment are major values in charismatic leadership. ${ }^{32}$

Due to that, charismatic leadership and its values are widely perceived by different organizational settings from public to private sectors. Despite sharing a common goal in delivering services to the mass in the setting of NGOs and RNGOs, charismatic leadership is shown to have a significant impact on factors of sensitivity to the environment, strategic vision, articulation, concern on members' needs and status quo consideration. ${ }^{33}$ These values are not alien to any religious teachings or principles, especially from the Islamic circle of leadership theory.

29 House, R. J. \& Baetz, M.L., 'Leadership: Some Empirical Generalizations and New Research Directions,' in Research in Organizational Behavior, ed. Staw, B.M. (Greenwich: JAI Press, 1979), 399-401.

30 Conger, Jay A. \& Rabindra N. Kanungo, 'Toward A Behavioral Theory of Charismatic Leadership in Organizational Settings,' Academy of Management Review, vol. 12/4 (1987): 637-647.

31 Willner, A. R., The Spellbinders: Charismatic Political Leadership (New Haven, CT: Yale University Press, 1984), 14.

32 Yukl, Gary., 'An Evaluation of Conceptual Weaknesses in Transformational and Charismatic Leadership Theories,' The Leadership Quarterly, vol. 10/2 (1999): 285-305.

33 Zehir, Cemal, Büşra Müceldili, Erkut Altindağ, Yasin Şehitoğlu \& Songül Zehir, 'Charismatic Leadership and Organizational Citizenship Behavior: The Mediating Role of Ethical Climate,' Social Behavior and Personality: An International Journal, vol. 42/8 (2014): 1365-1375. 
From an Islamic point of view, there are two types of charismatic leaders; ethical charismatic leaders and unethical charismatic leaders. Prophet Muhammad [pbuh] is the best role model for the former, who used power for the benefit of mankind, learnt from criticisms, produced future leaders after him and relied on an internal moral standard. All of these can be observed in the Qur'anic verses and the Prophet's sayings which describe that his companions' lives were much influenced by him. Dissimilar to the former, the latter refers to those who are motivated by self-interest, opposed any views and criticisms, as well as lacked moral code in their lives. ${ }^{34}$ In this sense, leaders of RNGOs should learn and be able to follow the footsteps of Prophet Muhammad [pbuh] in their leadership hierarchy, which applaud views, as well as criticisms and most importantly, to produce new leaders. By having dynamism in RNGO's operational system, a current leader should consider the following standards in organizing the next leader: organizational vision and mission are clearly articulated, organization's philosophy that is based on volunteerism, promote volunteerism among the youths, observe the multitaskers' outcomes and give rewards. ${ }^{35}$

\section{Transformational Leadership}

The four 'I's' are always referred to in defining transformational leadership. They are idealized charisma, inspiration, intellectual stimulation and individualized consideration, as emphasized by Bass (1995) and Avolio et al. (1991), the pioneer researchers in transformational leadership discussions. ${ }^{36}$ Apart from them, Pastor and Mayo insisted that transformational leaders can exert a strong influence on their followers by giving them a space of individualized consideration to discuss future possibilities that may lie within their selfsacrifice. ${ }^{37}$ Transformational leadership is believed to help in encouraging the followers' performance beyond organizational expectations. ${ }^{38}$ Hence, the

34 Beekun, Rafik Issa \& Jamal A. Badawi, Leadership: An Islamic Perspective (Beltsville, MD: Amana, 1999), 19.

35 Beekun, Rafik Issa \& Jamal A. Badawi, Leadership: An Islamic Perspective, 6972.

36 Dion, Michel, 'Are Ethical Theories Relevant for Ethical Leadership?' 4-24.

37 Carlos Pastor, Juan \& Margarita Mayo, 'Transformational Leadership among Spanish upper Echelons: The Role of Managerial Values and Goal Orientation,' Leadership \& Organization Development Journal, vol. 29/4 (2008): 340-358.

38 Sarros, James C. \& Joseph C. Santora, 'The Transformational-Transactional Leadership Model in Practice,' Leadership \& Organization Development Journal, vol. 22/8 (2001): 383-394. 
most central topic that surrounds transformational leadership is the ability to inspire and transform the followers towards a better ethical personality and self-development.

The important elements that would influence more in the transformational leadership are both personal and social identities, which later could affect the self-esteem and self-worth of individuals. In that sense, individual-focused and group-focused are the most affected groups as both being unique in terms of personality, vision, mission and objective. At the same time, they are easily influenced or imitated by others. ${ }^{39}$ Based on these empirical evidences, RNGOs are the platform that offer individuals or groups of people to enhance their ability to the next level by devoting themselves with arranged programs. Engagement between leaders and subordinates, as well as the public, are expected to be working great daily where zero bureaucracy is expected in nonprofit organizational settings like the RNGOs. For instance, one study revealed that NGOs with leaders who value similarities with peer organizations, grassroots approaches, diversity of strategies, dedication, professionalism and distributed organizational structures have significantly higher reputations for effectiveness. ${ }^{40}$ Therefore, the relationship between leaders and members within the organizations would indirectly enhance job performance. ${ }^{41}$

\section{Servant Leadership}

There are many interpretations of defining servant leadership. As the term 'servant' is assembling the association of leaders with religious teachings or principles as devoting himself to God, Han et al. stressed the possibility that 'servant leadership' could be interpreted very differently according to official religions of the country, such as Confucianism for China, Hinduism for India

39 Herman, H. M. \& Warren CK Chiu, 'Transformational Leadership and Job Performance: A Social Identity Perspective,' Journal of Business Research, vol. 67/1 (2014): 2827-2835.

40 Mitchell, George E., 'The Attributes of Effective NGOs and the Leadership Values Associated with A Reputation for Organizational Effectiveness,' Nonprofit Management and Leadership, vol. 26/1 (2015): 39-57.

${ }_{41}$ Loi, Raymond, Hang-Yue Ngo, Lingqing Zhang \& Victor P. Lau, 'The Interaction between Leader-Member Exchange and Perceived Job Security in Predicting Employee Altruism and Work Performance,' Journal of Occupational and Organizational Psychology, vol. 84/4 (2011): 669-685. 
and Islam for Muslim countries. ${ }^{42}$ They further identified that in China, for example, prioritizing the people's interest, behaving ethically, practicing moral love, possessing conceptual skills, building relationships, having humility, being a dutiful person, devoting to Party policies and state laws, as well as listening to public's problems are the dimensions of servant leadership. These dimensions are a combination of components from Confucianism, Daoism and Communist ideologies that bring forth the expression of servant leadership in China. ${ }^{43}$

In another literature of servant leadership, for example in the United States of America (USA), the Enron and World.com scandals in the corporate sector have opened a lot of eyes, where they are proofs that servant leadership receives wide attention in the North American context. Hence, a great discussion and interpretation on it have occurred extensively since then. Three dimensions are workable in applying servant leadership to North Americans, which are work situations, followers or staff and cultural judgments that are believed to be the parameters of servant leadership effectiveness. ${ }^{44}$

Servant leadership is a combination of two keywords: servant and leader. Robert K. Greenleaf was the first who questioned the possibility of both qualities in one person. Referring to Hesse's work, he said that 'the great leader is seen as servant first. ${ }^{45}$ This statement was Hesse's reflection when he was reporting on a figure named Leo in his Journey to the East. To him, Leo has shown a great personality as a servant, as well as the titular head of Order, a guiding spirit and a noble leader. ${ }^{46}$ Later, due to his reading on Journey to the East in the time of leadership crisis, Greenleaf became aware of the importance of having more servants emerging as leaders and following only servant-leaders. ${ }^{47}$

In general, scholars describe servant leadership as a behavior or leader characteristics that include humility, relational power, serviceorientation, follower development, encouragement autonomy, altruistic calling, emotional healing, persuasive mapping, wisdom and organizational

42 Han, Yong, Nada K. Kakabadse \& Andrew Kakabadse, 'Servant Leadership in the People's Republic of China: A Case Study of the Public Sector,' Journal of Management Development, vol. 29/3 (2010): 265-281.

43 Dion, Michel, 'Are Ethical Theories Relevant for Ethical Leadership?' 4-24.

44 Hale, Jeff R. \& Dail L. Fields, 'Exploring Servant Leadership Across Cultures: A Study of Followers in Ghana and the USA,' Leadership, vol. $3 / 4$ (2007): 397-417.

45 Hesse, Hermann, The Journey to the East: A Novel (Farrar: Straus and Giroux, 2013).

46 Greenleaf, Robert K., Servant Leadership (New York: Paulist Press, 1977), 19.

47 Greenleaf, Robert K., Servant Leadership, 21. 
stewardship. ${ }^{48}$ Another formulation that is available to explain the dimensions of servant leadership is the repetition and reflection of one's understanding of the servant leadership concept that is associated with a specific culture and religion. In other words, all traits that resemble servant leadership are within the following three major descriptions; service, humility and vision. ${ }^{49}$ Additional to Greenleaf's definition, Covey asserted that "the servant leadership concept is a principle, a natural law, and getting our social value systems and personal habits aligned with this ennobling principle is one of the great challenges of our lives". ${ }^{50}$ Hence, servant leadership is recognized as a valid and modern theory for organizational leadership including RNGOs. ${ }^{51}$

While most references on servant leadership denote Greenleaf's works, the works of Badawi and Beekun are in the same degree for the Islamic leadership framework. The idea of a leader as a servant in Islamic literature has been part of Islam since the beginning, which overturns Greenleaf's finding. According to Beekun and Badawi, leaders are servants of their followers; therefore, leaders seek the welfare of their followers and guide them towards good and prevent evils. This is by the sayings of Prophet Muhammad [pbuh]:

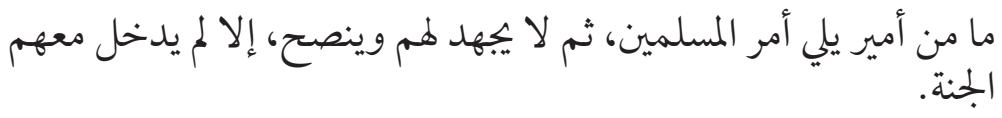

"A ruler who has been entrusted with the affairs of the Muslims, but makes no endeavor (for the material and moral upliftment) and is not sincerely concerned (for their welfare) will not enter paradise along with them." 52

48 Barbuto Jr, John E. \& Daniel W. Wheeler, 'Scale Development and Construct Clarification of Servant Leadership,' Group \& Organization Management, vol. 31/3 (2006): 300-326.

49 Hale, Jeff R. \& Dail L. Fields, 'Exploring Servant Leadership Across Cultures: A Study of Followers in Ghana and the USA,' 397-417.

50 Covey, Stephen R., 'Servant-leadership from the Inside Out,' in Insights on Leadership: Service, Stewardship, Spirit and Servant-leadership, ed. Spears, L. C (New York: John Wiley \& Sons, 1998), xi-xviii.

51 Russell, Robert F., 'The Role of Values in Servant Leadership,' Leadership \& Organization Development Journal, vol. 22/2 (2001): 76-84.

52 Muslim, Abī al-Ḥusayn Muslim Ibn al-Ḥajjāj Ibn al-Qushayrī al-Naysabūrī, Șaḥ̄hh Muslim, vol. 3, ed. Muhammad Fu'ād 'Abd al-Bāqī (Bayrūt: Dār Iḥyā' al-Turāth, n.d.), 1460, "Kitāb al-Imārah, Bāb Faḍ̄lah al-Imām al-'Adl wa 'Uqūbah al-Jā'ir wa al-Hath 'ala al-Rafaqa bi al-Ra'iyah wa al-Nahī 'an Idkhāl al-Mashaqqah 'Alayhim,” no. 22 (142). 
In another Prophet Muhammad [pbuh] saying, he says:

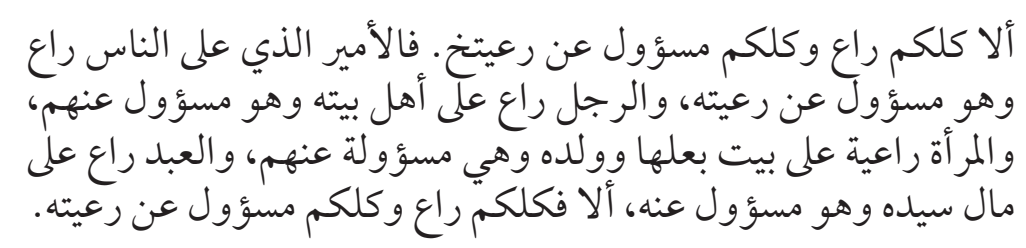

"All of you are guardians and are responsible for your wards. The ruler is a guardian and the man is a guardian of his family; the lady is a guardian and is responsible for her husband's house and his offspring, and so all of you are guardians and are responsible for your wards." 53

Based on the two Prophet's sayings above, it is explicitly clear that from an Islamic perspective, a leader is both a servant and guardian to his responsibilities that have been entrusted on his shoulder. Leadership in Islam is rooted in belief and willing submission to the Only Creator, which is Allah. Being a leader in Islam, one should encompass four domains that would ensure himself in the parameters of Allah's will. The four are Iman, Islam, taqwa and Ihsan. ${ }^{54}$ Though in Islam there is no specific term referring to a leader as a servant or guardian, even so, different terms are available in al-Quran or hadith such as imamah, khalifah, imarah or ra'iyyah; hence, the principles of leadership that are offered in Islam which as shown by the Prophet Muhammad [pbuh] should be a major concern among Muslim leaders in whatever organizational structures, including the Islamic RNGO type. ${ }^{55}$

\section{RELIGIOUS-NGOS IN MALAYSIA}

Religious-NGO is a formal organization that embeds identities and missions from the teachings of one or more religious or spiritual traditions. ${ }^{56}$ The

53 Muslim, Abī al-Ḥusayn Muslim Ibn al-Ḥajjāj Ibn al-Qushayrī al-Naysabūrī, Șahịh Muslim, vol. 3, 1458, "Kitāb al-Imārah, Bāb Faḍīlah al-Imām al-'Adl wa 'Uqūbah al-Jā'ir wa al-Ḥath 'ala al-Rafaqa bi al-Ra'iyah wa al-Nahī 'an Idkhāl al-Mashaqqah 'Alayhim," no. 20 (1829).

54 Beekun, Rafik Issa \& Jamal A. Badawi, Leadership: An Islamic Perspective, 19.

55 Omar, Mahyudin \& N.H. Abu Samah, 'The Basis of Leadership in Islam,' Advances in Natural and Applied Science, vol. 6/8 (2012): 1399-1404.

56 Berger, Julia, 'Religious Non-Governmental Organizations: An Exploratory Analysis,' Voluntas: International Journal of Voluntary and Nonprofit Organizations, vol. 14/1 (2003): 15-39. 
characteristics of an RNGO, as detailed by Berger, has to operate on a nonprofit, independent and voluntary basis to promote and realize articulated ideas collectively about the public's good either at the national or international level or in another word a 'moral' identity. It is interesting to note that there is a rising number of NGOs that have articulated themselves with the missions or teachings from 'religious' or 'spiritual' traditions or 'faith-based' understanding that is embedded in social activism or works. By having missions and objectives that are divinely guided and recognized by the sacred nature of human life, it would be an added value to the identity of an RNGO. As religious leaders can easily get close with the public, this may influence their grassroots to achieve a better life, as well as be committed individuals to their cause. ${ }^{57}$

Saliha Hasan insisted that the rhythm of Malaysian NGOs establishment in the 1970s was mainly concerned with the ranges of collaborative actions to confrontational results. This might change due to specific issues and moments of the people with the government for specific interests. Due to that, earlier organizations had been witnessed to have the intention of serving the circle of ethnic or religious communities which were often associated with mosques, churches, temples and other religious centers as their priorities. ${ }^{58}$ The scenario of separation also affected the establishment of RNGOs, including Islamic organizations where racial identity became the main concern.

As dated in March 2016, 1,215 organizations have entailed their identity to Islam, hence categorizing them as RNGOs. 67 of these organizations have inserted the word ' $d a$ ' $w a h$ ' as their primary objective. ${ }^{59}$ Three of them are Chinese-Muslim organizations, 55 are Indian-Muslim organizations while the rest are Malay-Muslim organizations. Despite the unity agenda promoted in Islam, in practice however, Malaysian Islamic RNGOs are disunited racially due to undefined circumstances such as communalism, where it is so ingrained in Malaysian lives. Additionally, there are also language barriers that complicate racial-communications. ${ }^{60}$

57 Saliha Hassan. 'Islamic Non-Governmental Organizations.' in Social Movements in Malaysia, ed. Meredith L Weiss, (London: Routledge, 2012), 105-107.

58 Meredith L. Weiss, ed. Social Movement in Malaysia (London: Routledge, 2012), 1.

59 Mohd Faridh Hafez Mhd Omar \& Sharifah Hayaati Syed Ismail, 'Sumbangan Organisasi Cina-Muslim dalam Keharmonian Beragama di Malaysia: Tinjauan Terhadap Cabaran dan Peranan PERKIM dan MACMA,' in Isu-Isu Semasa Dakwah dan Golongan Minoriti, ed. Raudah Haji Siren et al. (Kuala Lumpur: Akademi Pengajian Islam, Universiti Malaya, 2016), 1-27.

60 Osman Chuah Abdullah, Preaching to the Non-Muslim Chinese in Malaysia (Kuala Lumpur: IIUM Press, 2009), 82-85. 
Makmor Tumin gave an insightful explanation on the definition of NGOs in the current context of Malaysia. He said that 'the term NGO is used widely and ready for all bodies in Malaysia except political parties, labor unions, freemasons, cooperatives, military organizations, government bodies, and private organizations including several other small bodies' ${ }^{61}$ From this wide definition, he has set a degree of differences to all officially registered societies as NGOs. Those not mentioned above are mainly political parties, for-profit organizations and military purposes. Other categories of Malaysian NGOs have been enhanced by the great works of Tan Boon Kean and Bishan Singh into advocacy-oriented NGOs and government-organized NGOs (GONGOs). To them, these two types of NGOs, though basing their objectives on welfareoriented and issue-oriented NGOs, are not continuously aired up in the mainstream. They are believed to be seemingly apolitical welfare groups at one point and adopting a political stance at another critical time. ${ }^{62}$ Hence, it could be argued that these two types of NGOs are certainly within Makmor's NGO definition, or could be eliminated for the reason of adopting political stance.

In respect of Malaysian NGOs development, the range of civil society's motives such as agricultural extension activities, skills development and credit provision for the earlier groups, which are later followed by equal rights in education, language, culture for the Chinese, as well as religious groups that are mainly Islamic, are the flux that colors the landscape of Malaysian NGOs. Yet, referring them to the category of RNGOs from a Malaysian perspective is a new study.

\section{Malay Muslim NGOs}

Before the independence of Malaysia, the Malays witnessed new forms of associations emerging around the turn of the century, mainly literary, social, religious, and political. Meredith had given a brief topography of these organizations which in the first place was led by Malayo-Muslims

61 Makmor Tumin, 'NGO dalam Sistem Demokrasi Malaysia,' Massa, 16 Mei 1998, 62-63.

62 Kean, Tan Boon \& Bishan Singh, 'The Role of NGOs in Development-Malaysian Case Study,' in Uneasy Relations: The State and the NGOs in Malaysia (Kuala Lumpur: Gender and Development Programme, Asian and Pacific Development Center, 1994). 
(Arabs, Muslim Indians and Peranakans) rather than Malays. ${ }^{63}$ An economic competition from the Chinese had led these Malayo-Muslims to be involved in administration like NGOs. For the Malays, they changed and were encouraged gradually as a result of awareness which appealed towards pursuing economic development and cultural survival as Roff described:

"Perhaps the most notable feature of the cultural welfare and progress associations was how, despite their almost invariably local origins and circumscribed membership and their lack of direct contact with each other, they all practically without exception recognized the larger Malay society of which they were a part and spoke in holistic (if not necessarily nationalistic) terms of the task of improving the educational and economic status of the Malays within the plural society." 64

As a result of modern and educated Malays taking the lead in the main administrative sections in both government and private sectors, they have witnessed the emergence of 'progress associations' that encompass social, recreational or welfare orientation, political associations with a nationalist objective and economic associations as categorized by Meredith. ${ }^{65}$ Yet, all of them are not recognized specifically as (Islamic) RNGOs though by definition in Malaysia Federal Constitution, the Malays are those who profess Islam, speak Malay language, and practice Malay customs.

Saliha Hassan has opined the idea that NGOs are associated with Islamic principles and teachings as 'Islamic and/or Islamic-oriented NGOs or IONGOs'. ${ }^{66}$ This NGO specifically, IONGO, is believed to appear enjoying substantial grassroots goodwill within the Malay Muslim community that makes up 45 percent of the Malaysian population, which has risen to 59.3 percent today. In that sense, despite dominant Malay political parties like United Malay National Organization (UMNO) and Parti Islam Se-Malaysia (PAS), Saliha has categorized IONGO into two dimensions, which are government-

63 Meredith L. Weiss, 'Malaysian NGOs: History, Legal Framework and Characteristics,' in Social Movements in Malaysia, ed. Meredith L. Weiss (London: Routledge, 2012), 25.

64 Roff, William R., The Origins of Malay Nationalism (USA: Oxford University Press, 1994), 185.

65 Meredith L. Weiss, 'Malaysian NGOs: History, Legal Framework and Characteristics,' 25-28.

66 Saliha Hassan, 'Islamic Non-Governmental Organizations,' 97. 
sponsored Islamic NGOs and the da'wah movement. ${ }^{67}$ Persatuan Kebajikan Islam Malaysia (PERKIM), Lembaga Kebajikan Perempuan Islam (LKPI), Yayasan Dakwah Islam Malaysia (YADIM), Pergerakan Puteri Islam (PPI) and Institut Wasatiyyah Malaysia (IWM) are examples of the former, whereas Angkatan Belia Islam Malaysia (ABIM), Jemaah Islah Malaysia (JIM) and Pertubuhan Ikram Malaysia (IKRAM) are in the latter group.

The difference between the two can significantly be seen in enjoying the greater access to policy-making bodies, financial assistance and other facilities from the government like office, staffing and resources for the governmentsponsored Islamic NGOs. In other words, these constrain them within the framework of what is politically correct for the ruling government compared to non-government-sponsored Islamic NGOs who have got more freedom in making decisions, fund-raising, volunteerism and organizational objectives - which is a matter in this article, not the former. Currently, there is a new type of organization acting as a think-tank to the government and operates seemingly like an RNGO. Let us take IKSIM and IWM for example. They receive funds from the ruling government to conduct and publicize research that favors government policies. Acknowledging the establishment of (Islamic) RNGOs in Malaysia is due to promoting goodwill and preventing evils at large generally, yet the specific vision, mission and objectives of each organization are diverging towards the different available target market.

ABIM and IKRAM are among the prominent and active RNGOs in the Malaysian context. Their presence in voicing out to seek equality treatment among Malaysians, to protect religious affairs, to defend the educational system, to promote goodwill and to prevent evils is well known and has received wide attention from both national and international levels. Both RNGOs work to reach the public, as well as maintain the relationship within the internal employees, which is based on organizational vision and mission statements. This paper sought to explain ABIM as a sole representative of the Malay-based Islamic RNGOs in the Malaysian context.

\section{Angkatan Belia Islam Malaysia (ABIM)}

Established in August 6,1971 and officially registered in the following year, the Muslim Youth Movement of Malaysia or Angkatan Belia Islam Malaysia (ABIM) made it their objective to coordinate Muslim youth activism, with its outreach focusing primarily on educational activities in the early

67 Saliha Hassan, 'Islamic Non-Governmental Organizations,' 97. 
years. Later, ABIM began developing several vehicles for both missionary and economic agenda as its primary activism, locally and internationally. Recognized as a youth organization at the height of the global Islamic resurgence, ABIM was very much a product of its time. Against the backdrop of a staunchly secular government or in a modern term, a kleptocracy, ABIM sought to fill the gap by providing an avenue for the expression of Islamic ideals among Malaysia's Muslim majority community. ABIM managed to enhance its religious legitimacy and gain international recognition by maintaining excellent relations with Islamic countries regardless of differences that exist in the Muslim world. As a pressure group in the domestic sphere, ABIM is actively working with all parties such as the government, NGOs and the public - Muslims and non-Muslims - to bring good and peace to all Malaysians. ${ }^{68}$

However, different views were seen by scholars in the process of ABIM's establishment. For example, Mohd Fuad Mohd Salleh insisted that some Malay Muslim scholars, supported by teachers, university students and government staff, which all are inclined towards practicing Islamic teachings in daily life, were the cause of ABIM's establishment in the early days. ${ }^{69}$ According to Shaharuddin Badaruddin, the British imperialism on Tanah Melayu that left them with dualistic thinking, has resulted in the secularism understanding on the separation of religion and government, and it was a key factor as to why ABIM came into existence and was easily supported and accepted by the Malays, especially those with a good educational background. ${ }^{70}$ With their clear vision and mission statements, as well as their tagline 'agenda pembudayaan Islam' (Islamic cultural agenda), ABIM was considered to be the most influential and significant national Muslim youth organization in the 1970s, as claimed by Osman Bakar. ${ }^{71}$ He wrote that ABIM had successfully embedded its organizational structure and members within the five key elements that shaped itself. These were inclusivity, pioneering, intellectually oriented, taking a middle position and a hybrid of Eastern and Western ideologies and worldview, which they brought into a local context. Hence, the presence of ABIM as an Islamic RNGO in the Malaysian context was really timely and

68 Angkatan Belia Islam Malaysia, 'Profil Sejarah ABIM,' http://www.abim.org.my/ profil/sejarah-abim.html, accessed on 20th September 2017.

69 Mohd Fuad Mohd Salleh, Liku-liku Gerakan Islam di Malaysia: Satu Catatan Awal (Selangor: Imtiyaz Multimedia Publications, 2015), 61.

70 Shaharuddin Badaruddin, Masyarakat Madani dan Politik: ABIM dan Proses Demokrasi (Selangor: IDE Sdn. Bhd., 2016), 16.

71 Osman Bakar, 'An Intercultural Dialogue from within Muslim Communities: A Global Overview,' in Agree to Differ (UNESCO: Tudor Rose, 2015), 91-97. 
it is believed that it could change the understanding and practices of Malay Muslims into following the Shariah law, in hope to have a better living.

Before 46 years of ABIM's existence, there is some evidence suggesting that ABIM has strong leadership characters until today. Started recruiting members and leaders from its university student platform called Persatuan Kebangsaan Pelajar Islam Malaysia (PKPIM), it is proven that ABIM has the mechanism of organizational strength to be organized and is skillful in management. ${ }^{72}$ Referring to ABIM's presidential line-up, eight people have been the president; with the latest being Muhammad Faisal Abdul Aziz (32 years old). However, ABIM's leadership was truly felt during the time of Anwar Ibrahim, the second president from 1974 to 1982 due to his idealism, personal character, networking and enthusiasm. Despite receiving a very high reputation as an Islamic movement locally and internationally during Anwar's time, his decision to join politics under the banner of UMNO has twisted ABIM's direction then. Mohd Fuad emphasized that Anwar's decision to join politics had indirectly sunk ABIM's presence as jurubicara ummah or the voice of Muslims and slowed down its participation in the national arena due to the disbelief in Anwar's decision. ${ }^{73}$ This bitter situation faced by ABIM has indirectly made ABIM more mature in making decisions on their leadership process.

Considering ABIM's vision, "Membina dan memimpin tamadun dan khayra ummah", its contribution in developing the national building process is significant. With a clear position to act as a non-partisan entity - neither to ruling nor opposition parties in the Malaysian democracy system, ABIM has marked its presence by voicing out the interests of many in economics, education system, environmental issues, religious affairs and unity. Therefore, it can be seen under the current presidency, ABIM actively participates in numerous platforms to help the government and its agencies by offering ideas, solutions and affirmative actions to solve and curb problems that exist today. For example, ABIM's president is one of the committee members of Jawatankuasa Mempromosikan Persefahaman dan Keharmonian Antara Penganut Agama (JKMPKA) under the Prime Minister's Office of Malaysia

72 Shaharuddin Badaruddin, Masyarakat Madani dan Politik: ABIM dan Proses Demokrasi, 17.

73 Mohd Fuad Mohd Salleh, Liku-liku Gerakan Islam di Malaysia: Satu Catatan Awal, 62. 
for the next two years. ${ }^{74}$ This steering committee was developed to discuss and find ways to integrate Malaysian multiracial and multi-religious people to unite and at the same time respect the differences. Through this platform, ABIM is actively organizing community programs, inter-faith dialogues and forums to promote a better understanding among the religious adherents. ABIM's roles in Friendship Group Inter-faith Services (FGIS), an interreligious platform consisting of six main religions in Malaysia - Buddhism, Christianity, Hinduism, Sai Baba, Sikhism, is a proof that ABIM's leadership is a step ahead within the circle of Malay-based Islamic RNGOs.

In 2015, ABIM's leadership was recognized by the Ministry of Youth and Sports (KBS) as a youth NGO that has reached a high standard of organizational management and administration with a 'five stars' scale. ${ }^{75}$ This is a big achievement for ABIM as an Islamic RNGO compared to other competitors that have more capabilities to win. This recognition is undoubtedly a reflection of leadership characters that have enshrined from ABIM's leaders, as well as how they lived with their vision and mission statements, which can be translated into charismatic, transformational and servant leadership as the main characteristics.

\section{Chinese Muslim NGOs}

According to Hicks, Chinese organizations have been developed in a wide range of locus since the time of colonial Malaya, such as clan organizations, commercial and industrial organizations, cultural bodies, political parties and privately funded organizations. ${ }^{76}$ Being actively involved in mining, plantation, agriculture, small-scale manufacturing, as well as retail and distribution sectors, is the key to shaping Malayan Chinese leadership that was led by successful merchant entrepreneurs. As time passed by, in order to sustain a leading group in the economic sector, these organizations were gradually turned into a political

74 N.a, 'JKMPKA, mekanisme pertingkat kefahaman dan keharmonian'. Utusan Borneo Online, https://www.utusanborneo.com.my/2016/02/25/jkmpkamekanisme-tingkat-persefahaman-dan-keharmonian, accessed on 28 September 2017

75 Angkatan Belia Islam Malaysia Page. https://www.facebook.com/media/set/?set $=\mathrm{a} .1105872269425425 .1073741909 .126121114067217 \&$ type $=3$, accessed on 28 September 2017.

76 Hicks, George, 'Chinese Organizations in Southeast Asia in the 1930s,' in Social Movement in Malaysia, ed. Saliha Hassan \& Meredith L. Weiss. (Singapore: Select Books, 1996), 76-90. 
setting in response to nationalist and revolutionary groups that occurred in China, such as the Communist and the Kuomintang party. ${ }^{77}$ However, these groups excluded the minority groups, especially Chinese-Muslims who were converting from their original religion into Islam.

\section{Malaysian Chinese Muslims Association (MACMA)}

Malaysian Chinese Muslim Association (MACMA) is the oldest organization that represents the Chinese-Muslim community in Malaysia. Before its awareness, it is important to have an official organization that understands well about the sociocultural background that is embodied in the Chinese Muslims in the Malaysian context. MACMA was officially registered on September 8th, 1994. There were huge efforts by several early Chinese Muslim professionals to register MACMA as an official NGO, especially in gaining strong support from the Minister in the Prime Minister Office, YB Dato' Dr. Abdul Hamid Othman due to the increasing number of Chinese who reverted to Islam (or some called it converting) year by year. Therefore, the presence of MACMA helped promote Islamic teachings to new Chinese Muslims in the context of Chinese sociocultural understanding, as well as in the realm of the Syāri'ah circle directly. At the same time, they would be more sensitive towards the Chinese and the non-Chinese Muslims, and the Chinese communities indirectly.

With strong support by many, it became imperative for MACMA to extend their accessibilities not only to the central of Malaysia such as Kuala Lumpur and Selangor, but to expand their offices. Due to the enthusiasm that has embroiled within their volunteers, as well as their leadership today, MACMA has expanded into 19 branches that cover all 13 states of Malaysia in five districts. One branch in Batu Pahat, Johor is currently waiting for approval from the Registrar of Society (ROS). ${ }^{78}$ Statistically, the members of MACMA in 2014 had increased to 2,586, from 2,560 in 2013 and 2,432 in 2012. ${ }^{79}$ However, there are no updated data for 2015 onwards.

77 Meredith L. Weiss, 'Malaysian NGOs: History, Legal Framework and Characteristics,' 20.

78 Persatuan Cina Muslim Malaysia (MACMA), 'MACMA Branches,' http://macma. my/main/index.php/macma-branches/, accessed on 27 September 2017.

79 Mohd Faridh Hafez Mhd Omar \& Sharifah Hayaati Syed Ismail, 'Sumbangan Organisasi Cina-Muslim dalam Keharmonian Beragama di Malaysia: Tinjauan Terhadap Cabaran dan Peranan PERKIM dan MACMA.' There is no updated data on MACMA's membership as shown in the website. 
Leadership in MACMA is divided into two segments which are for national and state levels, as stated in MACMA's new constitution. Every two years in their Annual General Meeting (AGM), the members have the right to vote for new leadership and those who got elected will be in position for the following two years. In 2015, Prof. Dr. Taufiq Yap Yun Hin became the third president of MACMA at the national level. The first president was Hj. Sulaiman Hon, followed by Datuk Dr. Mustapha Ma. The third president of MACMA, Prof. Dr. Taufiq Yap Yun Hin, was a well-known chemist and recognized by the International Union of Pure and Applied Chemistry (IUPAC), an international chemist union. He then received an award as a Fellow of Academy of Science Malaysia. As stressed by one of the MACMA members, it is hoped that under the third president, MACMA will transform its presence into a global key player who has great mind settings that contribute to the development of Islam and be part of the world's Muslim communities, not only as Chinese Muslims in the Malaysian context. ${ }^{80}$

Another contribution from Chinese Muslim leadership in Malaysia could be seen from how they develop their identities in the context of a multiracial environment. To date, four mosques had been built on Chinese architectural and identities; all popularly known as 'Masjid Cina' or Chinese Mosque. The location of these mosques is in Rantau Panjang, Kelantan; Ipoh, Perak; Seremban, Negeri Sembilan and Melaka. The initiative to build these Chinese Mosques in Malaysia was originally inspired by the Niujie Mosque in Beijing, aging more than 1,000 years. These mosques aim to act as a translocal agent to the community where religious and social activities intersect. However, in terms of the mosques' management, it falls under the state law by which it has to follow all related enactments such as the language of sermon, appointment of an imam (prayer leader) and funds, that is directly under the order of Sultan.

Contextually, the notion that MACMA leadership has to actively participate in the Malaysian development is really in time. It can be seen clearly from the recognition that MACMA's members receive every year. For example, one of the members and volunteers of MACMA had received the Anugerah Tokoh Maal Hijrah, a special award given to those actively contributing in the da wah field in promoting goodwill and preventing evils, as well as effortlessly calling people to Islam, including leadership skills that entail along the process, neither state nor national level. This year, 1439 Hijrah, four of MACMA members received numerous awards from the states of Kedah,

80 Xifu Naser, 'Cina Muslim Perlu Bangkit,' Sinar Harian Online, http://www. sinarharian.com.my/politik/cina-muslim-perlu-bangkit-1.399109, accessed on 27 September 2017. 
Kelantan and Pulau Pinang. ${ }^{81}$ In this sense, leadership characters in MACMA as one of the respected Islamic RNGOs are important to adopt and should be a central principle in delivering good services to the community. Charismatic, transformational and servant leadership are well embedded in the works of MACMA leaders, volunteers and members. These characters are aligned with the vision and mission statements of MACMA since its establishment and have reflected on the organizational effectiveness and achievements, not individuals.

\section{Indian Muslim NGOs}

The Indian community has established itself in an organization since the time of the colonized Malaysia. Caste, linguistic, economic, and educational divisions are the parameters that define their movement establishment, not the homogeneous view of cultural identity or sense of belonging. ${ }^{82}$ Yet, the western-educated and professional minority has maintained prominence as an elite within the community, mainly in the aspects of income and access to power. According to Meredith, the earliest organizations within the Indian community are religious, youth, social and guilds. In contrast, Rajoo then found that Indian organizations tend to stress on in-group identity and highlight differences across sub-communities. For example, the Indian Muslim community is well associated with the Malay Muslims rather than the Indian Hindus. ${ }^{83}$ Like Malay and Chinese communities, upon post-independence, the Indian community has also become a key member of the nation-building process through its involvement in the political-based organization. Yet, the Indian Muslim community was segregated from their agenda due to differences in religion and belief system. To date, there are 700,000 Indian Muslims scattered in different fields, such as businesses, restaurants, retails and religious affairs management. ${ }^{84}$

81 Persatuan Cina Muslim Malaysia (MACMA). http://macma.my/main/, accessed on 27 September 2017.

82 Meredith L. Weiss, 'Malaysian NGOs: History, Legal Framework and Characteristics,' 22.

83 Rajoo. R., 'World view of the Indians with Regard to Their Social Identity and Belonging in Malaysia,' in Malaysian Worldview, ed. Mohd Taib Osman (Singapore: ISEAS, 1985), 155.

84 Budiwanti, Erni, 'Malaysian Indian Muslim's Oscillating Identity: Swinging Between Home and Host Countries,' in From Conflict to Peace Building and Democratization: Muslim Minorities in Southeast Asia (Thailand: API Regional Coordinating Institutions, 2012), 81-87. 


\section{Federation of Indian Muslim Malaysia Associations (PERMIM)}

In the spirit of pooling different interests under one official umbrella instead of living in differences, as a minority Muslim in the Malaysian context, early generation of Indian Muslims took a very good initiative by establishing Persekutuan Pertubuhan India Muslim Malaysia or Federation of Malaysian Indian Muslim Associations (PERMIM). PERMIM was officially registered in 1973 and acted as a sole NGO that represents the interests and rights of Malaysian Indian Muslims. Before its establishment, 40 social and religious organizations had merged under PERMIM and fought for the interest of many. ${ }^{85}$

Referring to PERMIM's mission statement, three points will lead this organization to move forward. One of them stated being a research facility by offering services to envisage, as well as organizing and implementing activities to promote religion, education, economy, social, and culture well to its members and public. ${ }^{86}$ Considering the mission and programs that are conducted by PERMIM along with its establishment, it can be said that PERMIM is a type of Islamic RNGO which is not only driven by ethnic interests per se, but religious motives and teachings implanted within the organization and its members.

The current PERMIM's leadership is led by Hj. Dhajudeen B. Shahul Hameed, the President of PERMIM for 2016 until 2018. However, detailed information about him has not been made available in any channels, including PERMIM's official website. Despite such limited knowledge and reports, the presence of PERMIM leadership is very much felt in the Indian Muslim development process in Malaysia. According to Budiwanti, building a mosque within their circle is a must and the first step to be taken is to unite all Indian Muslims under the spirit of Islam. ${ }^{87}$ Budiwanti further explained that six mosques have been identified that were built with Indian architecture; with the oldest one located in Melaka, Masjid Tengkera, and Masjid Kampung Klling, followed by Masjid Kapitan Keling in Penang and Masjid Sultan Kelana in Klang, Selangor. Surprisingly, in Kuching, Sarawak, there is one Indian Mosque that is believed to be built in 1837. In 2014, according to reports, the

85 PERMIM, 'Heritage,' http://www.permim.org/index.php/aboutus/heritage, accessed on 27 September 2017.

86 PERMIM, 'Vision,' http://www.permim.org/index.php/aboutus/vision, accessed on 27 September 2017.

87 Budiwanti, Erni, 'Malaysian Indian Muslim's Oscillating Identity: Swinging Between Home and Host Countries,' 84. 
Sarawak state government agreed to relocate and rebuild this historical mosque to a new venue, sitting on the Sarawak River along the Sarawak Waterfront Esplanade. The project was expected to take 18 months to complete and would be ready by 2018 [85]. ${ }^{88}$ Thus, these huge contributions from PERMIM and its involvement in spreading out the teachings of Islam and all its principles are undeniably driven by strong leadership that encroaches all leadership characters as discussed earlier. Nevertheless, a deeper and focused study has to be conducted in the future as information on PERMIM is very limited and not well-studied academically.

\section{CONCLUSION}

This writing is intended to re-conceptualize the understanding of leadership characters accordingly in the new landscape and presence of Malaysian Islamic RNGOs divided by three major races. All three selected Islamic RNGOs were chosen based on different racial backgrounds, years of establishment, clear vision and mission statements, contributions towards Islamic development, as well as having a strong leadership line-up. It is proven from the literature review that the leadership characteristics which are charismatic, transformational and servant leadership are well adopted and practiced by these Islamic RNGOs that can be seen through their achievements, recognitions, and programs organized. Thus, they transverse racial limitations, raise the values of Islamic principles and reach organizational and leadership arrangements.

In respect to the disputable and never-ending discussions on defining the meaning of leadership, these three Islamic RNGOs, however, are wellmanaged and constructively executing all visions and missions towards their members and the public. The best explanation on the application of these three leadership characters can be seen from the outcomes, contributions, and recognitions that the organizations and their members have received, which will benefit people at large regardless of their origins. Therefore, the three lead characters as discussed could be proposed as a yardstick to effective RNGO leadership development in the future.

88 Borneo Post, 'Kuching City Floating Mosque Ready,' http://borneobulletin.com. bn/kuching-city-floating-mosque-ready-2018/, accessed on 27 September 2017. 


\section{REFERENCES}

Andek Kelawa, A.M., Kepimpinan Wanita dalam Islam: Kedudukannya dalam Syariah (Female Leadership in Islam: Status in Shariah). (Bangi: Penerbit Universiti Kebangsaan Malaysia, 1999).

Angkatan Belia Islam Malaysia, 'Profil Sejarah ABIM,' http://www.abim.org. my/profil/sejarah-abim.html, accessed on 20th September 2017.

Balkundi, P. \& Kilduff, M., 'The Ties that Lead: A Social Network Approach to Leadership,' The Leadership Quarterly, vol. 17 (2006): 419-439.

Barbuto Jr, John E. \& Daniel W. Wheeler, 'Scale Development and Construct Clarification of Servant Leadership,' Group \& Organization Management, vol. 31/3 (2006): 300-326.

Beekun, Rafik Issa \& Jamal A. Badawi, Leadership: An Islamic Perspective (Beltsville, MD: Amana, 1999).

Berger, Julia, 'Religious Non-Governmental Organizations: An Exploratory Analysis,' Voluntas: International Journal of Voluntary and Nonprofit Organizations, vol. 14/1 (2003): 15-39.

Borneo Post, 'Kuching City Floating Mosque Ready,' http://borneobulletin. com.bn/kuching-city-floating-mosque-ready-2018/, accessed on 27 September 2017.

Budiwanti, Erni, 'Malaysian Indian Muslim's Oscillating Identity: Swinging Between Home and Host Countries,' in From Conflict to Peace Building and Democratization: Muslim Minorities in Southeast Asia (Thailand: API Regional Coordinating Institutions, 2012), 81-87.

Burns, James, Leadership (New York: Harper \& Row, 1978).

Carlos Pastor, Juan \& Margarita Mayo, 'Transformational Leadership among Spanish upper Echelons: The Role of Managerial Values and Goal Orientation,' Leadership \& Organization Development Journal, vol. 29/4 (2008): 340-358.

Carter, D.R., DeChurch, L. A., Braun, M. T. \& Contractor, N. S., 'Social Network Approaches to Leadership: An Integrative Conceptual Review,' Journal of Applied Psychology, vol. 100/3 (2015): 597-622.

Chin, D. T., \& Wendy A. Smith, 'An Inductive Model of Servant Leadership: The Considered Difference to Transformational and Charismatic Leadership,' Working Paper 43/06, Department of Management, Monash University (2006), 1-19. 
Conger, Jay A. \& Rabindra N. Kanungo, 'Toward A Behavioral Theory of Charismatic Leadership in Organizational Settings,'Academy of Management Review, vol. 12/4 (1987): 637-647.

Connaughton, M. J., \& Hassinger, J. 'Leadership character: antidote to organizational fatigue.' Journal of Nursing Administration, vol. 37/10 (2007): 464-470.

Covey, Stephen R., 'Servant-leadership from the Inside Out', in Insights on Leadership: Service, Stewardship, Spirit and Servant-leadership, ed. Spears, L. C (New York: John Wiley \& Sons, 1998), xi-xviii.

Dansereau, F., Jr., Graen, G. \& Haga, W. J., 'A Vertical Dyad Linkage Approach to Leadership within Formal Organizations: A Longitudinal Investigation of the Role Making Process,' Organizational Behavior and Human Performance, vol. 13 (1975): 46-78.

DeRue, D. S. 'Adaptive Leadership Theory: Leading and Following as a Complex Adaptive Process,' Research in Organizational Behavior, vol. 31 (2011): 125-150.

Dinh, J. E. \& Lord, R. G., 'Implications of Dispositional and Process Views of Traits for Individual Difference Research in Leadership,' The Leadership Quarterly, vol. 23/4 (2012): 651-669.

Dinh, J. E., Lord, R. G., Gardner, W. L., Meuser, J. D., Liden, R. C. \& Hu, J., 'Leadership Theory and Research in the New Millennium: Current Theoretical Trends and Changing Perspectives,' The Leadership Quarterly, vol. 25/1 (2014): 36-62.

Dion, Michel, 'AreEthicalTheories RelevantforEthicalLeadership?' Leadership \& Organization Development Journal, vol. 33/1 (2012): 4-24.

Eberly, M. B., Johnson, M. D., Hernandez, M. \& Avolio, B. J., 'An Integrative Process Model of Leadership: Examining Loci, Mechanisms, and Event Cycles,' American Psychologist, vol. 68 (2013): 427-443.

Fernandez, R. M., 'Structural Bases of Leadership in Intraorganizational Networks,' Social Psychology Quarterly, vol. 54 (1991): 36-53.

Follet, M. P., 'Power,' in Dynamic Administration: The Collected Papers of Mary Parker Follet, ed. H. C. Metcalf \& L. Urwick (New York: Harper, 1925).

French, J. R. P. \& Raven, B., 'The Bases of Social Power', in Studies in Social Power, ed. D. Cartwright (Ann Arbor: University of Michigan, 1959). 
Friedrich, T.L., Vessey, W.B., Schuelke, M.J., Ruark, G.A., \& Mumford, M.D., 'A Framework for Understanding Collective Leadership: The Selective Utilization of Leader and Team Expertise within Networks,' The Leadership Quarterly, vol. 20 (2009): 933-958.

Ghere, R. K., 'NGO Leadership and Human Rights,' http://ecommons. udayton.edu/cgi/viewcontent.cgi? article $=1045 \&$ context $=$ pol_fac_pub, accessed on 21 September 2017.

Gibb, C.A., 'Leadership,' in Handbook of social psychology, ed. G. Lindzey (Reading, MA: Addison Wesley, 1954).

Gill, Roger, Theory and Practice of Leadership (London: Sage Publications, 2013).

Greenleaf, Robert K., Servant Leadership (New York: Paulist Press, 1977).

Hackman, J.R. \& Wageman, R., 'Asking the Right Questions about Leadership: Discussion and Conclusions,' American Psychologist, vol. 62 (2007): 43-47.

Hailey, J. \& James, R., 'Trees Die from the Top: International Perspectives on NGO Leadership Development,' Voluntas: International Journal of Voluntary and Nonprofit Organizations, vol. 15/4 (2004): 343-353.

Hale, Jeff R. \& Dail L. Fields, 'Exploring Servant Leadership Across Cultures: A Study of Followers in Ghana and the USA,' Leadership, vol. 3/4 (2007): 397-417.

Han, Yong, Nada K. Kakabadse \& Andrew Kakabadse, 'Servant Leadership in the People's Republic of China: A Case Study of the Public Sector,' Journal of Management Development, vol. 29/3 (2010): 265281.

Herman, H. M. \& Warren CK Chiu, 'Transformational Leadership and Job Performance: A Social Identity Perspective,' Journal of Business Research, vol. 67/1 (2014): 2827-2835.

Hesse, Hermann, The Journey to the East: A Novel (Farrar: Straus and Giroux, 2013).

Hicks, George, 'Chinese Organizations in Southeast Asia in the 1930s,' in Social Movement in Malaysia. ed. Saliha Hassan \& Meredith L. Weiss. (Singapore: Select Books, 1996), 76-90.

Hogg, M. A., 'A Social Identity Theory of Leadership,' Personality and Social Psychology Review, vol. 5 (2001): 184-200.

Hollander, E. P., \& Julian, J. W., 'Contemporary Trends in the Analysis of Leadership Processes,' Psychological Bulletin, vol. 71 (1969): 387-397. 
Hollander, E. P., 'Legitimacy, Power, and Influence: A Perspective on Relational Features of Leadership,' in Leadership Theory and Research: Perspectives and Directions, ed. M. M. Chemers \& R. Ayman (San Diego, CA: Academic Press, 1993).

House, R. J. \& Baetz, M.L., 'Leadership: Some Empirical Generalizations and New Research Directions,' in Research in Organizational Behavior, ed. Staw, B.M. (Greenwich: JAI Press, 1979).

Howell, J. M. \& Shamir, B., 'The Role of Followers in the Charismatic Leadership Process: Relationships and their Consequences,' Academy of Management Review, vol. 30 (2005): 96-112.

Hussain, Muzaffar, 'The Islamic Polity of Abdul A'la al-Mawdudi,' VFAST Transactions on Islamic Research, vol. 3/1 (2014): 13-21.

Javidan, Mansour \& David A. Waldman, 'Exploring Charismatic Leadership in the Public Sector: Measurement and Consequences,' Public Administration Review, vol. 63/2 (2003): 229-242.

Jay Lorsch, 'A Contingency Theory of Leadership,' in Handbook of Leadership Theory and Practice, ed. Nitin Nohria \& Rakesh Kurana (Boston, MA: Harvard Business Press, 2010).

Jayakody, J. A. S. K., 'Charismatic Leadership in Sri Lankan Business Organizations,' Journal of Management Development, vol. 27/5 (2008): 480-498.

Johnson, R.E., 'Not all Leader-Member Exchanges are Created Equal: Importance of Leader Relational Identity,' The Leadership Quarterly, vol. 21/5 (2010): 796-808.

Kean, Tan Boon \& Bishan Singh, 'The Role of NGOs in DevelopmentMalaysian Case Study,' in Uneasy Relations: The State and the NGOs in Malaysia (Kuala Lumpur: Gender and Development Programme, Asian and Pacific Development Center, 1994).

Khan, A. (2007), 'Islamic leadership principles-a model of success for everyone at all times,' http://www.irfi.org/articles/articles_1401_1450/ islamic_leadership_principles.html, accessed on 27 September $2 \overline{0} 17$.

Klein, K. J. \& House, R. J. 'On fire: Charismatic Leadership and Levels of Analysis,' The Leadership Quarterly, vol. 6 (1995): 183-198.

Loi, Raymond, Hang-Yue Ngo, Lingqing Zhang \& VictorP. Lau, 'The Interaction between Leader-Member Exchange and Perceived Job Security in Predicting Employee Altruism and Work Performance,' Journal of Occupational and Organizational Psychology, vol. 84/4 (2011): 669685. 
Lord, R.G. \& Dinh, J.E., 'Whathave we Learned that is Critical in Understanding Leadership Perceptions and Leader-Performance Relations? Industrial and Organizational Psychology,' Perspectives on Science and Practice, vol. 7 (2014): 158-177.

Makmor Tumin, 'NGO dalam Sistem Demokrasi Malaysia,' Massa, 16 Mei 1998, 62-63.

Meindl, J. R., 'The Romance of Leadership as a Follower-Centric Theory: A Social Constructionist Approach,' The Leadership Quarterly, vol. 6 (1995): 329-341.

Meredith L. Weiss, 'Malaysian NGOs: History, Legal Framework and Characteristics,' in Social Movements in Malaysia, ed. Meredith L. Weiss (London: Routledge, 2012).

Michael, H. Hart, The 100: A Ranking of the Most Influential Persons in History (New York: Kensington Publishing Corporation, 1978).

Mitchell, George E., 'The Attributes of Effective NGOs and the Leadership Values Associated with A Reputation for Organizational Effectiveness,' Nonprofit Management and Leadership, vol. 26/1 (2015): 39-57.

Mohd Faridh Hafez Mhd Omar \& Sharifah Hayaati Syed Ismail, 'Sumbangan Organisasi Cina-Muslim dalam Keharmonian Beragama di Malaysia: Tinjauan Terhadap Cabaran dan Peranan PERKIM dan MACMA,' in Isu-Isu Semasa Dakwah dan Golongan Minoriti, ed. Raudah Haji Siren et al. (Kuala Lumpur: Akademi Pengajian Islam, Universiti Malaya, 2016), 1-27.

Mohd Fuad Mohd Salleh, Liku-liku Gerakan Islam di Malaysia: Satu Catatan Awal (Selangor: Imtiyaz Multimedia Publications, 2015).

Mohd. Yusof, Aminuddin, Kepimpinan (Leadership) (Kuala Lumpur: Dewan Bahasa dan Pustaka, 1990).

Morgeson, F.P., DeRue, D.S. \& Karam, E.P., 'Leadership in Teams: A Functional Approach to Understanding Leadership Structures and Processes,' Journal of Management, vol. 36 (2010): 5-39.

Mumtaz Ahmad, 'Religious Scholars in the Modern World,' (Paper presented, the Madrasah Convention organized by MUIS, 15-16 March 2013).

Nabeel Al-Azami, Muhammad 11 Leadership Qualities that Changed the World (California: Claritas Books, 2019).

Omar, Mahyudin \& N.H. Abu Samah, 'The Basis of Leadership in Islam,' Advances in Natural and Applied Science, vol. 6/8 (2012): 13991404. 
Osborn, R. N., Hunt, J. G. \& Jauch, L. R., 'Toward A Contextual Theory of Leadership,' The Leadership Quarterly, vol. 13 (2002): 797-837.

Osman Bakar, 'An Intercultural Dialogue from within Muslim Communities: A Global Overview,' in Agree to Differ (UNESCO: Tudor Rose, 2015), 91-97.

Osman Chuah Abdullah, Preaching to the Non-Muslim Chinese in Malaysia (Kuala Lumpur: IIUM Press, 2009).

Pearce, C. L. \& Conger, J. A., Shared Leadership: Reframing the Hows and Whys of Leadership (Thousand Oaks, CA: Sage Publication, 2003).

PERMIM, 'Heritage,' http://www.permim.org/index.php/aboutus/heritage, accessed on 27 September 2017.

PERMIM, 'Vision,' http://www.permim.org/index.php/aboutus/vision, accessed on 27 September 2017.

Persatuan Cina Muslim Malaysia (MACMA), 'MACMA Branches,' http://macma.my/main/index.php/macma-branches/, accessed on 27 September 2017.

Pigors, P. J. W., Leadership or Domination (Boston, MA: Houghton Mifflin, 1935).

Politis, John D., 'Transformational and Transactional Leadership Enabling (Disabling) Knowledge Acquisition of Self-Managed Teams: The Consequences for Performance,'Leadership \& Organization Development Journal, vol. 23/4 (2002): 186-197.

Rajoo. R., 'World view of the Indians with Regard to Their Social Identity and Belonging in Malaysia,' in Malaysian Worldview, ed. Mohd Taib Osman (Singapore: ISEAS, 1985).

Roff, William R., The Origins of Malay Nationalism (USA: Oxford University Press, 1994).

Russell, Robert F., 'The Role of Values in Servant Leadership,' Leadership \& Organization Development Journal, vol. 22/2 (2001): 76-84.

Safi, L., 'Leadership and Subordination: An Islamic Perspective,' The American Journal of Islamic Social Sciences, vol. 12/2 (1995): 204-223.

Sarros, James C. \& Joseph C. Santora, 'The Transformational-Transactional Leadership Model in Practice,' Leadership \& Organization Development Journal, vol. 22/8 (2001): 383-394.

Shaharuddin Badaruddin, Masyarakat Madani dan Politik: ABIM dan Proses Demokrasi (Selangor: IDE Sdn. Bhd., 2016). 
Uhl-Bien, M., 'Relational Leadership Theory: Exploring the Social Processes of Leadership and Organizing,' The Leadership Quarterly, vol. 17 (2006): 654-676.

White, S. C., Devine, J. \& Jha, S., 'The Life A Person Lives: Religion, Wellbeing and Development in India,' Development in Practice, vol. 22/5-6 (2012): 651-662.

Willner, A. R., The Spellbinders: Charismatic Political Leadership (New Haven, CT: Yale University Press, 1984).

Xifu Naser, 'Cina Muslim Perlu Bangkit,' Sinar Harian Online, http://www. sinarharian.com.my/politik/cina-muslim-perlu-bangkit-1.399109, accessed on 27 September 2017.

Yammarino, F., 'Leadership Past, Present, and Future,' Journal of Leadership \& Organizational Studies, vol. 20 (2013): 149-155.

Yukl, G. A., Leadership in Organizations (7th ed.) (New Jersey: PearsonPrentice Hall, 2010).

Yukl, Gary., 'An Evaluation of Conceptual Weaknesses in Transformational and Charismatic Leadership Theories,' The Leadership Quarterly, vol. 10/2 (1999): 285-305.

Zehir, Cemal, Büşra Müceldili, Erkut Altindağ, Yasin Şehitoğlu \& Songül Zehir, 'Charismatic Leadership and Organizational Citizenship Behavior: The Mediating Role of Ethical Climate,' Social Behavior and Personality: An International Journal, vol. $42 / 8$ (2014): 1365-1375. 
Jurnal Syariah, Jil. 29, Bil. 1 (2021) 91-126 